\title{
RESPONSE OF SENSITIVE CORN HYBRIDS TO THE ASSOCIATION OF NICOSULFURON AND TIMING OF NITROGEN APPLICATION
}

\author{
Heitor Franco de Sousa ${ }^{1 *}$, Paulo César Timossi² ${ }^{2}$ Antônio Paulino da Costa Netto², Claudio Hideo Martins Costa² \\ IInstituto Federal do Triangulo Mineiro (IFTM), Campus Ituiutaba-MG, Rua Belarmino Vilela, Av. Belarmino Vilela Junqueira, S/N - Novo \\ Tempo II, 38305-200 \\ 2Universidade Federal de Jatai (UFJ), Câmpus Jatobá - Cidade Universitária-GO, BR 364, km 195, nº 3800, 75801-615, ptimossi2004@ \\ yahoo.com.br, apcnetto@yahoo.com.br, c_hideo@hotmail.com.br \\ *Autor para correspondência: Heitor Franco de Sousa, hfffranco@live.com
}

\begin{abstract}
Nicosulfuron is an herbicide used in corn crop for controlling weeds, some hybrids are sensitivity to nicosulfuron even more when it is applied near to the application of nitrogen fertilizers. Thus, this study aimed to evaluate the response of sensitive corn hybrids to association of urea and coated urea applied near to nicosulfuron application on V4 corn stage. P 3646 hybrid was the most sensitive, and urea and coated urea applied near to nicosulfuron had significant effect on corn growth for all hybrids. Most hybrids showed high or significant $(p<0.10)$ correlation coefficients for grain yield, cob length and row per ear. SYN 7341 hybrid was the one that showed better results in grain yield with urea and nicosulfuron combination. Coated urea should not be applied after V8corn stage when nicosulfuron is applied at $\mathrm{V} 4$.
\end{abstract}

Keywords: Coated urea, acetolactate synthase, herbicide, phytotoxicity

\section{RESPOSTA DE HÍBRIDOS DE MILHO SENSÍVEIS À ASSOCIAÇÃO DE NICOSULFURON E PERÍODO DE APLICAÇÃO DE NITROGÊNIO}

RESUMO: Nicosulfuron é um herbicida usado em lavouras de milho para controlar gramíneas, alguns híbridos mostram sensibilidade ao herbicida mais ainda quando é aplicado próximo a uma aplicação de fonte nitrogenada. Assim, este estudo objetivou avaliar a resposta de híbridos de milho sensíveis a associação da aplicação de ureia e ureia revestida próximo a aplicação de nicosulfuron no estágio V4. O híbrido P 3646 foi o mais sensível, ureia e ureia revestida próximo ao nicosulfuron teve um efeito significativo no crescimento de todos os híbridos. Maioria dos híbridos apresentaram um alto ou significante $(p<0.10)$ coeficientes de correlação entre produção de grãos, comprimento de espiga e linha de grãos por espiga. O híbrido SYN 7341 foi o que teve um resultado melhor na produção de grãos com a combinação de ureia e nicosulfuron. Ureia revestida não deve ser aplicada após estágio V8 do milho quando nicosulfuron for aplicado no V4.

PALAVRAS-CHAVE: Ureia revestida, acetolactato sintase, herbicida, fitotoxidade

\section{INTRODUCTION}

The average second-season corn grain yield in Midwestern Brazil is $6098 \mathrm{~kg} \mathrm{ha}^{-1}$ and the state of Goiás is the second most productive, with average of $6342 \mathrm{~kg} \mathrm{ha}^{-1}$ (Conab, 2017). Farmers challenge to reach higher yields due to resistant weeds, water deficit, pests and diseases (Giachini et al., 2017). Researchers and agronomists became an important source of information, because they aim to develop the best management practices to farmers who search for higher yields.

Since herbicides became a tool for weed management, farmers frequently use them due to their efficiency and benefits (Shaner and Beckie, 2014). Among the herbicide options to be used in corn crops, glyphosate became the most used worldwide and as consequence, there are 10 dicots and 13 monocots resistant weeds, and corn is the second crop, with 58 resistant biotypes (Heap, 2014). The reliance of herbicides is due to weed interference period, which might alter plant growth and mainly final grain yield (Faria et al.,2014; Knezivic and Datta,2015). A review study on weed interference showed that weed can reduce corn grain yield in USA and Canada by $52 \%$ (Soltani et al., 2016). Recently, a field study on weed 
interference in southeastern Brazil showed reduction in corn grain yield of 54\% (Campos et al., 2016).

Farmers are concerned about crop safety, because some herbicides can cause injuries and phytotoxicity that might harm final yields. Thus, farmers require information about these herbicides, so they can decide when, how and which management should be used for better weed control. Furthermore, herbicide can enhance crop yields by an effect named hormesis, and many researchers have reported this effect by glyphosate on corn (Velini et al., 2008), bromoxynil on oat (Wiedman and Appleby, 1972), metsulfuron-methyl on barley (Cedergreen, 2008), and simazine on wheat (Ries et al., 1970). Information related to herbicide enhancement and the correlation of traits in corn crops under herbicide application is still scarce.

Among herbicides for corn crops, nicosulfuron is a POST herbicide that controls weeds by inhibiting ALS enzyme (Acetolactate Synthase), which is responsible for synthesizing branched-chain amino acids (Gallaher et al., 1970; Stankiewicz-Kosyl et al., 2017). Many farmers in Midwestern Brazil do not use nicosulfuron because corn is sensitive to it. In addition, nicosulfuron application near to nitrogen fertilizer with fast nitrogen release enhances its phytotoxicity and can reduce plant height and grain yield (Nicolai et al., 2006; Guerra et al., 2010). A recent study on the timing of nitrogen application near nicosulfuron did not show significant effect on corn grain yield (Rodrigues et al., 2012). So far, the influence of nicosulfuron applied near nitrogen fertilizer has only been tested using fertilizer with quick nitrogen release such as urea, ammonium sulfate and ammonium nitrate (Nicolai et al., 2006; Guerra et. al., 2010; Rodrigues et. al., 2012); moreover, a better understanding on the timing of nitrogen application near nicosulfuron is needed. Therefore, this study aimed to evaluate the response of sensitive corn hybrids to nicosulfuron applied near to different types of urea.

\section{MATERIAL AND METHODS}

A field trial was conducted in Midwestern Brazil at the Federal University of Goiás, campus Jatai with Aw type climate, located at $17^{\circ} 55^{\prime} 32^{\prime \prime} \mathrm{S}$ and $51^{\circ} 42^{\prime}$ 32 " W and $685 \mathrm{~m}$ a.s.l. Four corn hybrids sensitive to nicosulfuron were sown in 03/02/2017: LG 3040 (145 CRM), NS 90 (145 CRM), P 3646 (135 CRM) and SYN 7341 (135 CRM). Before sowing, millet was sown (30 $\mathrm{kg} \mathrm{ha}^{-1}$ of seed) when it reached $30 \mathrm{t}$ ha-1 of green biomass, glyphosate was applied at $2 \mathrm{~L} \mathrm{ha}^{-1}$. A vacuum corn/soybean planter with six rows $0.45 \mathrm{~m}$ spaced from each other was used to apply $400 \mathrm{~kg} \mathrm{ha}^{-1}$ of fertilizer 8-20-18, aiming to reach around 6-8 $\mathrm{t} \mathrm{ha}^{-1}$ (Sousa and Lobato, 2004). The field soil was composed of $21.5 \%$ sand, $67.2 \%$ clay and $11.1 \%$ silt and classified as Oxisol (Embrapa, 2006).

The field trial was set in a randomized complete block design in a $(5 \times 2+2)$ factorial arrangement with three replicates. Each plot consisted of three planting rows with six meters in length. One factor was type of urea (urea and coated urea), the other factor was the timing of urea application ( 4,2 days before, at the same day, 2 and 4 days after nicosulfuron application), and the two control treatments were urea and coated urea applied at V4 corn stage without herbicide (Magalhães et al., 2002). Nicosulfuron formulation was SANSON applied at V4 corn stage using a backpack $\mathrm{CO}_{2}$ sprayer, with three nozzles TT $1100150.45 \mathrm{~m}$ spaced from each other and calibrated to deliver $150 \mathrm{~L} \mathrm{ha}^{-1}$ at 2 bars (200 Kpa).

Corn phytotoxicity was visually estimated 7, 14 and 21 days after herbicide application (DAH) according to EWRC scale from 1 (no effect) to 9 (total plant and yield loss) (EWRC, 1964). Corn responsible variables included growth delay percentage at 21 and $35 \mathrm{DAH}$, in which a second trial was set with the same treatments, design and plot size but no herbicide was applied, and the height of plants from the center row of each treatment and trial were measured by metric ruler from the bottom to the last visible collar. Then, a formula was used to determine the growth delay percentage: $Y_{i j}(\%):\left(Z_{i} \times 100 / X_{i}\right)-100$ where $Z_{i}=$ mean plant height with nicosulfuron at i observation and $X_{j}=$ mean plant height without nicosulfuron at j observation. Stem diameter was determined by measuring the stem of five plants at $42 \mathrm{DAH}$ from the center row with a digital caliper rule at $10 \mathrm{~cm}$ above the soil surface. Plants at five meters from the center row were harvest to determine cob and seed length, row per ear and 500 grain weight and grain yield. Eight corn cobs were used to measure cob and seed length by a metric ruler, row per ear and 500 grain weight from the cob center. Corn grain yield was determined by weighting all seeds, calculating the weight to $13 \%$ of grain humidity and converted into $\mathrm{kg} \mathrm{ha}^{-1}$

All data were checked for homogeneity using the Levine test, if necessary, transformed into 
$1 / X\left(H 1^{\circ}\right)$ or $1 / X^{2}\left(H 2^{\circ}\right)$. Type of urea and timing of urea application were fixed effects and replicate as random effect. Fixed effects and their interaction with growth delay percentage were submitted to ANOVA $(p<0,05)$, correlation between corn traits and timing of urea application and regression of corn grain yield over timing of urea application were analyzed by $R$ 3.3.3 and means were compared using the Fisher LSD test $(p<0.05)$.

\section{RESULTS AND DISCUSSION}

P 3646 and NS 90 hybrids were more sensitive than LG 3040 and SYN 7341, for showing severe injuries and strong chlorosis at $7 \mathrm{DAH}$, highlighting that chlorosis and injuries disappear for LG 3040 and SYN 7342, but not for P 3646 and NS90 (data not shown).

Coated urea applied near to nicosulfuron application showed the highest growth delay percentage for P $3646(17.70 \%)$ at $21 \mathrm{DAH}$ and $(12.11 \%)$ at $35 \mathrm{DAH}$ (Table 1). The slowest percentage was observed using coated urea for NS 90 (3.73\%), LG 3040 (3.91\%) and with urea for P 3646 (5.7\%) at $35 \mathrm{DAH}$ (Table 1). At 21 $\mathrm{DAH}$, urea and coated urea had more effect on most hybrids before herbicide application, but at $35 \mathrm{DAH}$, urea had more effect before herbicide application and after coated urea application for most hybrids.

Table 1. Effect of slow and quick nitrogen release applied near nicosulfuron application on the growth delay of corn hybrids

\begin{tabular}{|c|c|c|c|c|c|c|c|c|c|}
\hline \multirow{2}{*}{\multicolumn{2}{|c|}{ Treatment ${ }^{\text {a }}$}} & \multicolumn{4}{|c|}{21 days after nicosulfuron application ${ }^{b}$} & \multicolumn{4}{|c|}{35 days after nicosulfuron application ${ }^{b}$} \\
\hline & & NS 90 & LG 3040 & P 3646 & SYN 7341 & \multirow[t]{2}{*}{ NS 90} & LG 3040 & P 3646 & \multirow[t]{2}{*}{ SYN 7341} \\
\hline & & & $\%$ & & & & & & \\
\hline Quick & -4 & $12.27 \mathrm{ab}$ & $7.97 \mathrm{bc}$ & $15.00 \mathrm{bc}$ & $7.83 \mathrm{e}$ & $5.07 \mathrm{bc}$ & $10.33 a b$ & $7.88 \mathrm{~cd}$ & $4.85 \mathrm{bc}$ \\
\hline Quick & -2 & $10.93 \mathrm{~b}$ & $10.97 a$ & $14.40 \mathrm{~cd}$ & $12.97 \mathrm{ab}$ & $6.29 a b$ & 11.56 a & $9.55 \mathrm{~b}$ & $7.30 \mathrm{a}$ \\
\hline Quick & 0 & $10.53 \mathrm{~b}$ & $7.80 \mathrm{bc}$ & $10.67 \mathrm{f}$ & $10.47 \mathrm{bc}$ & $6.91 \mathrm{a}$ & $5.27 \mathrm{f}$ & $8.84 \mathrm{bc}$ & 7.64 a \\
\hline Quick & 2 & $10.70 \mathrm{~b}$ & $6.20 \mathrm{~d}$ & $16.27 a b$ & $6.60 \mathrm{f}$ & $4.61 \mathrm{c}$ & $8.47 \mathrm{~cd}$ & $5.70 \mathrm{f}$ & $6.29 a b$ \\
\hline Quick & 4 & $8.17 \mathrm{c}$ & 10.73 a & 10.93 ef & $8.53 \mathrm{de}$ & $5.79 a b$ & 7.77 de & $6.91 \mathrm{e}$ & $4.12 \mathrm{c}$ \\
\hline Slow & -4 & $14.37 \mathrm{a}$ & $8.67 a b$ & $11.53 \mathrm{e}$ & $12.70 \mathrm{ab}$ & $4.44 \mathrm{~cd}$ & $7.39 \mathrm{e}$ & $12.11 \mathrm{a}$ & $4.88 \mathrm{bc}$ \\
\hline Slow & -2 & $8.67 \mathrm{c}$ & $8.33 \mathrm{bc}$ & $17.70 \mathrm{a}$ & $11.73 b$ & $6.20 \mathrm{a}$ & $3.91 \mathrm{~g}$ & $10.02 b$ & $7.41 \mathrm{a}$ \\
\hline Slow & 0 & $12.03 \mathrm{ab}$ & $9.70 a b$ & $13.53 \mathrm{~d}$ & $9.30 \mathrm{~cd}$ & $3.98 \mathrm{de}$ & $5.32 \mathrm{f}$ & $9.79 \mathrm{~b}$ & $4.08 \mathrm{c}$ \\
\hline Slow & 2 & $10.77 \mathrm{~b}$ & $6.97 \mathrm{~cd}$ & $14.57 \mathrm{bcd}$ & $6.23 \mathrm{f}$ & $3.73 \mathrm{e}$ & $9.41 \mathrm{bc}$ & $7.53 \mathrm{de}$ & 6.75 a \\
\hline Slow & 4 & $11.63 \mathrm{~b}$ & $6.80 \mathrm{~d}$ & $13.90 \mathrm{~cd}$ & $16.67 \mathrm{a}$ & $6.51 \mathrm{ab}$ & $11.77 \mathrm{a}$ & $7.66 \mathrm{~d}$ & $6.34 a b$ \\
\hline Quick & $C$ & 0 & 0 & 0 & 0 & 0 & 0 & 0 & 0 \\
\hline Slow & $C$ & 0 & 0 & 0 & 0 & 0 & 0 & 0 & 0 \\
\hline Urea $(U)^{c}$ & & 0.0179 & 0.146 & $<0.01$ & $<0.01$ & $<0.01$ & $<0.01$ & $<0.01$ & 0,8242 \\
\hline Period $(\mathrm{P})^{c}$ & & $<0.01$ & $<0.01$ & $<0.01$ & $<0.01$ & $<0.01$ & $<0.01$ & $<0.01$ & $<0,01$ \\
\hline$U: P^{d}$ & & $<0.02$ & $<0.01$ & $<0.01$ & $<0.01$ & $<0.01$ & $<0.01$ & $<0.01$ & $<0,01$ \\
\hline LSD (U : P)e & & 0.00229 & 0.026277 & 0.000967 & 0.01905 & 0.01694 & 0.01595 & 0.014189 & 0,0471 \\
\hline $\mathrm{CV}(\mathrm{U}: \mathrm{P})^{f}$ & & 16.56 & 13.49 & 11.00 & 11.35 & 27.18 & 7.27 & 7.40 & 18,66 \\
\hline Transformatio & & $\mathrm{H} 2^{\circ}$ & $\mathrm{H} 1^{\circ}$ & $\mathrm{H} 2^{\circ}$ & $\mathrm{H} 1^{\circ}$ & $\mathrm{H} 1^{\circ}$ & $\mathrm{H} 1^{\circ}$ & $\mathrm{H} 1^{\circ}$ & $\mathrm{H} 1^{\circ}$ \\
\hline \multicolumn{10}{|c|}{ a Combination of factors type of urea and timing of urea application } \\
\hline \multicolumn{10}{|c|}{ b Means followed by the same letter within column are not significantly different according to the Fisher LSD test $p<0.05$} \\
\hline \multicolumn{10}{|c|}{ c Probability values from separated factors are significant if $p<0.05$} \\
\hline \multicolumn{10}{|c|}{$d$ Probability values from the interaction of factors are significant if $p<0.05$} \\
\hline \multicolumn{10}{|c|}{ e Least Significant Difference values from the interaction of factors } \\
\hline \multicolumn{10}{|c|}{ f Coefficient of Variance values from the interaction of factors } \\
\hline Abbreviation & $\mathrm{C}-\mathrm{C}$ & $\mathrm{H} 2^{\circ}$ and $\mathrm{H}$ & data transfo & & & & & & \\
\hline
\end{tabular}

Although growth delay percentage was not compared between day 21 and 35 DAH (Table 1), a slight decrease on the growth delay for both urea and coated urea for most hybrids was observed (Table 1). 
Perhaps the plant has metabolized the nicosulfuron concentration at $35 \mathrm{DAH}$, thus the apical meristem growth could keep its cell division rate. In situation of increasing the percentage, niculfuron couldn't be metabolized, bulliform and fundamental cells growth would be suppressed (Môro and Damião Filho,1999). Most nicosulfuron translocation within plants is to apical meristems (Gallaher et al., 1970).

The interaction between nicosulfuron and urea or coated urea affects the vegetative growth of corn plants, thus farmers that intend to harvest corn for silage will have green biomass and yield losses. Similar result was observed in a study of corn tolerance to nicosulfuron rates, where plants from control treatment were higher than plants from all nicosulfuron treatments (Cavalieri et al., 2008).

Results from the correlation of LG 3040 using urea were significant for row per year and timing of application, grain yield and grain weight, grain yield and cob length, while using coated urea did not show any correlation (Table 2). NS 90 hybrid showed significant correlation between cob length, grain size and row per year when using urea, while coated urea showed only one correlation between grain yield and timing of application (Table 2). P 3646 hybrid showed significant correlation for urea and nicosulfuron between grain yield, timing of application and row pear year (Table 2). It was observed that coated urea had lower significant correlation compared to urea, probably due to the interaction of herbicide and low nitrogen release. Although, most of hybrids showed a correlation coefficient over 0.30 for grain yield, row pear ear and cob length under both nitrogen source. Correlation between corn grain yield, 100 grain weight and cob length were observed in a study of correlation for various grain traits (Ali and Ashan, 2015). In addition, significant correlation between corn grain yield and one thousand grain weight was observed in a study carried out in southern Brazil on nitrogen management in no-tillage corn system (Kappes et al., 2014).

Table 2. Pearson correlation coefficients between corn traits and timing of urea application in four corn hybrids

\begin{tabular}{|c|c|c|c|c|c|c|c|c|c|c|c|c|c|}
\hline \multicolumn{14}{|c|}{ LG 3040} \\
\hline \multicolumn{7}{|c|}{ UREA } & \multicolumn{7}{|c|}{ COATED UREA } \\
\hline & Time & Weight & Size & Yield & Row & Length & & Time & Weight & Size & Yield & Row & Length \\
\hline Time & & & & & & & Time & & & & & & \\
\hline Weight & -0.020 & & & & & & Weight & -0.390 & & & & & \\
\hline Size & 0.128 & 0.123 & & & & & Size & -0.150 & -0.165 & & & & \\
\hline Yield & 0.051 & $0.443^{*}$ & 0.388 & & & & Yield & -0.130 & -0.330 & 0.185 & & & \\
\hline Row & $0.745^{\star}$ & 0.392 & 0.118 & 0.332 & & & Row & 0.010 & -0.179 & 0.144 & 0.200 & & \\
\hline Length & 0.034 & -0.021 & -0.200 & $0.566^{*}$ & 0.214 & & Length & 0.338 & 0.244 & 0.000 & -0.410 & 0.085 & \\
\hline \multicolumn{14}{|c|}{ NS 90} \\
\hline & Time & Weight & Size & Yield & Row & Length & Time & Time & Weight & Size & Yield & Row & Length \\
\hline Time & & & & & & & Time & & & & & & \\
\hline Weight & -0.230 & & & & & & Weight & -0.140 & & & & & \\
\hline Size & -0.170 & 0.122 & & & & & Size & -0.080 & 0.276 & & & & \\
\hline Yield & -0.250 & 0.359 & 0.351 & & & & Yield & $0.560^{*}$ & -0.060 & 0.131 & & & \\
\hline Row & -0.110 & -0.144 & 0.167 & 0.295 & & & Row & 0.116 & 0.213 & 0.438 & 0.127 & & \\
\hline Length & -0.110 & $0.469^{*}$ & $0.561^{*}$ & 0.175 & $-0.546^{*}$ & & Length & -0.020 & 0.347 & 0.436 & 0.310 & 0.215 & \\
\hline \multicolumn{14}{|c|}{ P 3646} \\
\hline & Time & Weight & Size & Yield & Row & Length & & Time & Weight & Size & Yield & Row & Length \\
\hline Time & & & & & & & Time & & & & & & \\
\hline Weight & 0.023 & & & & & & Weight & -0.040 & & & & & \\
\hline Size & -0.200 & $0.555^{\star}$ & & & & & Size & 0.381 & -0.219 & & & & \\
\hline Yield & $0.446^{*}$ & -0.128 & 0.001 & & & & Yield & -0.250 & 0.230 & 0.126 & & & \\
\hline Row & 0.307 & -0.438 & 0.055 & $0.553^{*}$ & & & Row & -0.020 & -0.310 & -0.037 & 0.179 & & \\
\hline Length & 0.183 & -0.089 & 0.069 & -0.173 & -0.180 & & Length & 0.141 & 0.078 & 0.339 & -0.090 & 0.004 & \\
\hline \multicolumn{14}{|c|}{ SYN 7341} \\
\hline & Time & Weight & Size & Yield & Row & Length & & Time & Weight & Size & Yield & Row & Length \\
\hline Time & & & & & & & Time & & & & & & \\
\hline Weight & 0.102 & & & & & & Weight & -0.020 & & & & & \\
\hline Size & -0.190 & 0.122 & & & & & Size & 0.063 & 0.049 & & & & \\
\hline Yield & $0.507^{*}$ & -0.152 & -0.27 & & & & Yield & -0.300 & -0.045 & 0.224 & & & \\
\hline Row & -0.240 & $-0.907^{\star}$ & 0.059 & 0.057 & & & Row & 0.431 & $-0.537^{*}$ & 0.141 & 0.096 & & \\
\hline Length & 0.129 & 0.258 & -0.06 & -0.119 & -0.150 & & Length & 0.221 & 0.345 & $0.562^{*}$ & 0.280 & 0.157 & \\
\hline
\end{tabular}

* - Significant at $p<0.10$ 
Regression analysis (Figure 1) showed a decreasing tendency for grain yield when urea was applied days after nicosulfuron application for LG 3040, NS 90 and P 3646, only for SYN 7341, there was an increasing tendency. Studies on nitrogen use efficiency and nitrogen recovery showed an enhancement on corn grain yield, nitrogen recovery and efficiency using coated urea (Gagnon et al., 2012; Guareshi et al., 2013; Martins et al., 2014; Valderrama et al., 2014). Although coated urea has shown improvements in corn yield, this nitrogen source could not be efficient applied after V8 corn stage because a 1\% decrease was observed in Brazil on grain yield applying coated urea at V8 corn stage (Kappes et al., 2014). Our research observed 3.61, 1.6 and $7.8 \%$ increase for $L G$ 3040, P 3646 and NS 90 in grain yield when coated urea was applied days after nicosulfuron application at V4 corn stage. Perhaps, nitrogen applied at planting was enough, so plants needed a high nitrogen ratio after corn stage $\mathrm{V} 4$.

Figure 1. Response of grain yield by the association of nicosulfuron and urea (black dots) and coated urea (white dots) timing of urea application

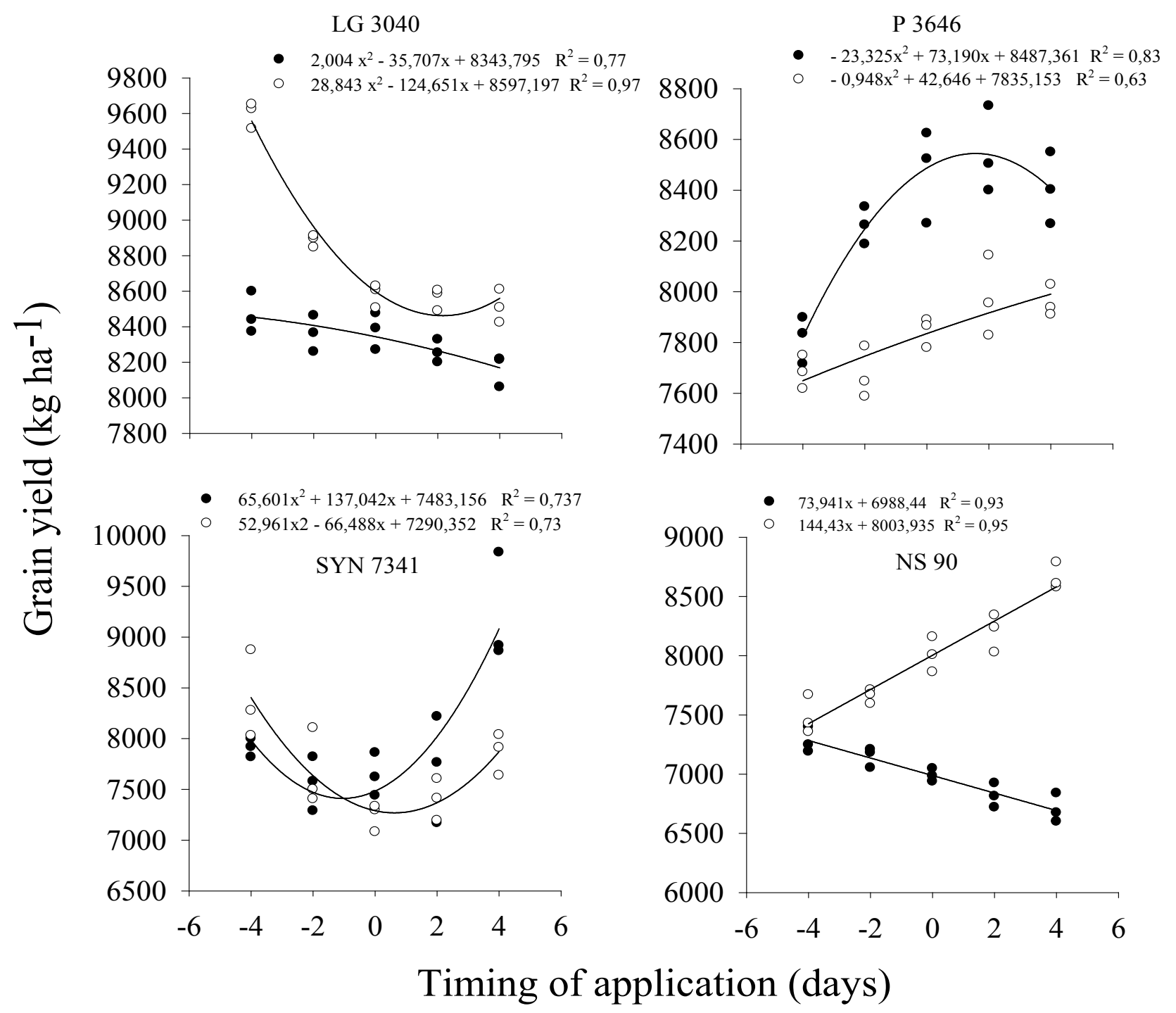

Thus, nicosulfuron and any nitrogen source will affect corn plant growth, but will not affect grain yield, being an option for farmers to be used in their corn crops.

\section{ACKNOWLEDGEMENT}

All the authors are grateful to Brazilian National Council of Technological and Scientific Development (CAPES) for granting students with scholarship to the master degree program of the Federal University of Jataí. 


\section{REFERENCES}

Ali, Q.; Ahsan, M. Correlation analysis for various grain contributing traits of Zea mays. African Journal of Agricultural Research, 2015, 10, 23, 2350-2354.

Campos, C.F.; Barros, A.M.M.; Silva Junior, A.C.; Gonçalves, C.G.; Martins, D. Periods of weed interference in maize crops cultivated in the first and second cycles. Sem.: Ciências Agrárias, 2016, 37, 5, 2867-2880.

Cavalieri, S.D.; Oliveira Junior, R.S.; Constantin, J.; Biffe, D.F.; Rios, F.A.; Franchini, L.H.M. Tolerância de híbridos de milho ao herbicida nicosulfuron. Planta Daninha, 2008, 26, 1, 203-214.

Cedergreen, N. Herbicide can stimulate plant growth. Weed Research, 2008, 48, 1-10.

CONAB. $4^{\circ}$ Levantamento - Safra 16/17 - Grãos, 2017, 162p.Available in: <https://www.conab.gov.br/info-agro/ safras/graos/boletim-da-safra-de-graos? start $=20>$. Access in: December, 21, 2017.

EWRC. Report of $3^{\text {rd }}$ and $4^{\text {th }}$ meetings of EWRC. Committee of Methods in Weed Research. Weed Research, 1964, 4. 88p.

EMBRAPA. Sistema brasileiro de classificação de solo. Rio de Janeiro: Embrapa - SPI, 2006, 2, 286p.

Faria, R.M.; Barros, R.; Tuffi Santos, L.D. Weed interference on growth and yield of transgenic maize. Planta Daninha, 2014, 32, 3, 515-520.

Gagnon, B.; Ziadi, N.; Grant, C. Urea fertilizer forms affect grain corn yield and nitrogen use efficiency. Canadian Journal of Soil Science, 2012, 92, 2, 341-351.

Gallaher, K.; Muller, T.C.; Hayes, R.M.; Schwartz, O.; Barrett, M. Absorption, translocation, and metabolism of primisulfuron and nicosulfuron in broadleaf signalgrass (Brachiara platyphylla) and corn. Weed Science, 1970, 47, 1, 746-748.

Giachini, R.M.; Ferreira, R.L.; dos Santos, C.A.R.; da Silva A.G.; Rech, J.; de Fátima Fernandes, A; da Silva, A.F. Panorama dos sistemas de produção de milho safrinha na região Centro-Oeste de Nordeste do Brasil. Emprapa Milho e Sorgo (INFOTECA-E), 2017, 282-320.

Guareshi, R.F.; Perin, A.; Gazolla, P.R.Produtividade de milho submetido à aplicação de ureia revestida por polímeros. Global Science and Technology, 2013, 6, 2, 31-37.

Guerra, N.; de Goes Maciel, C.D.; de Oliveira Neto, A.M.; Poletine, J.P.; de Ramos Lima, G.G.; Júnior, L.C.S. Seletividade de formulações de nicosulfuron para híbridos de milho função da época da adubação nitrogenada. Revista Brasileira de Herbicida, 2010, 9, 3, 89-99.

Heap, I. Herbicide resistant weeds. In: Pimentel, D.; Peshing, R. Integrated Pest Management, Springer: Dordrecht, 2014, 281-301.

Kappes, C.; Aarf, O.; Dal Bem, E.A.; Portugal, J.R.; Gonzaga, A.R.Manejo de nitrogênio em cobertura na cultura do milho em sistema de plantio direto. Revista Brasileira Milho e Sorgo, 2014, 13, 2, 201-217.

Knezivic, S.Z.; Datta, A. The critical period for weed on growth and yield of transgenic maize. Weed Science, 2015, 63(SP1), 188-202.

Martins, I.S.; Cazetta, O.J.; Fokuda, A.J.F. Condições, modos de aplicação e doses de ureia revestida por polímeros na cultura do milho. Pesquisa Agropecuária Tropical, 2014, 44, 3, 271-279.

Magalhães, P.C.; Durães, F.O.M.; Carneiro, N.P.; Paiva, E. Fisiologia do milho. Embrapa Milho e Sorgo - Circular Técnica 22, 2002, 23p.

Môro, F.V.; Damião Filho, C.F.A. Alterações morfoanatômicas das folhas de milho submetidas à aplicação de nicosulfuron. Planta Daninha, 1999, 17, 3, 331-337.

Nicolai, M.; Ovejero, R.L.; Carvalho, S.J.P.; Moreira, M.S.; Christoffoleti, P.J. Efeitos de adubação nitrogenada em cobertura sobre a seletividade de herbicidas à cultura do milho. Planta Daninha, 2006, 24, 2, 279-286.

Ries, S.K.; Moreno, O.; Meggitt, W.F.; Schweizer, C.J.; Ashkar, S.A. Wheat seed protein: chemical influence 
and relationship to subsequence growth and yield in Michigan and Mexico. Agronomy Journal, 1970, 62, 746-748.

Rodrigues, M.J.; Turozi, T.A.; Netto, A.P.C.; Timossi, P.C. Épocas da adubação nitrogenada relacionada à aplicação de nicosulfuron na cultura do milho. Global Science Technology, 2012, 5, 1, 70-77.

Shaner, D.L.; Beckie, H.J. The future for weed control and technology. Pest Management Science, 2014, 70, 9, 1329-1339.

Soltani, N.; Dille, J.A.; Burke, I.C.; Everman, W.J.; VanGessel, M.J.; Davis, V.M.; Sikkema, P.H. Potential corn yield losses from weeds in north america. Weed Technology, 2016, 30, 4, 979-984.

Sousa, D.M.G.; Lobato, E. Calagem e adubação para culturas anuais e semiperenes. In: Sousa, D.M.G.; Lobato, E. Cerrado: correlação do solo e adubação, Embrapa Informação Tecnológica: Brasília, 2004, 283315.
Stankiewicz-Kosyl, M.; Wrochna, M.; Salas, M.; Gawronski, S.W. A strategy of chemical control of Apera spica-venti $L$. resistant to sulfonylureas traced on the molecular level. Journal of Plant Protection Research, 2017, 57, 2, 113-119.

Valderrama, M.; Buzetti, S.; Teixeira Filho, M.C.M.; Sabin Benett, C.G.; Andreotti, M. Adubação nitrogenada na cultura do milho com ureia revestida por diferentes fontes de polímeros. Ciências Agrárias, 2014, 35, 2, 659-670.

Velini, E.D.; Alves, E.; Godoy, M.C.; Meschede, D.K.; Souza, R.T.; Duke, S.O. Glyphosate at low dose can stimulate plant growth. Pest Management Science, 2008, 64, 4, 489-496.

Wiedman, S.J.; Appleby, A.P. Plant growth stimulation by sublethal concentration of herbicides. Weed Research, 1972, 12, 1, 65-74. 